\title{
NEOMARXISME - KULTUURKRITIEK TUSSEN DIE MISLUKKING VAN DIE REVOLUSIE IN DIE OOSTE EN DIE VERSUIM VAN DIE REVOLUSIE IN DIE WESTE*
}

\author{
J.M. Kirsten, Departement Filosofie, Universiteit van Port Elizabeth
}

ABSTRACT

This introdustion to "Neomarxism" begins by a formal analysis of the concept itself. It is suggested here that this term refers to the philosophical revival and revision of Marxist theory in the West. The philosophic-historical context of Neomarxism is consequently outlined so as to elucidate the basic elements of this revision. It appears that this context is determined by the dual experience of the betrayed revolution in the East and the abandoned revolution in the West. Against this background an explanation is then given as to why Neomarxist criticism of Marx concentrates especially on the so-called reductivist and deterministic elements in historical materialism. Finally the leitmotif of the Neomarxist critique of culture is defined. Their rejection of the technocratic idsal of progress not only demonstrates their departure from Marx and the Marxist belief in the emancipatory effect of the rational control of nature. In addition it justifies the view that a radical critique of Marx simultaneously implies a critique of the very roots of modern Weslern society.

Dit is vir my 'n aangename voorreg om met $u$ te kan gedagtes wissel oor 'n onderwerp wat só warm uit die intellektuele oond kom soos die Neomarxisme - tans een van die invloedrykste filosoficse bewegings in die Westerse wèreld.

Ek moet ook ruiterlik erken dat ek gevlei vocl deur die wete dat u meerendeel beoefenaars van dic empiriese wetenskappe - kans sien om na 'n lang en vermoeiende dag 'n filosoof van alle mense aan te hoor. Dit is na alle waarskynlikheid nie omdat $u$ begin om terug te verlang na die spekulatiewe vleispotte van die filosofie nie. Daarom moet ek u by voorbaat waarsku dat ck nie u gunsteling akademiese gereg op die spyskaart het nic. Ek gaan nie vanmiddag harde, objektiewe feite opdis nie. Ook die filosoof is uitgelewer aan die waarheid van die Nederlandse spreukwoord wat lui dat "Elk vogeltje zingt zoals het gebekt is". Die lewenselement van die filosoof is - Voordrag gelewer op 25 Mei voor die Oos-Kaaplandse Werkgemeenskap van die Suid-
Alrikaanse Akadenie vir Wetenskap en Kuns te Port Elizabeth.

Koers, 47(3) 1982 
nou cenmaal nie die cmpiriese orde van feite wat gekontroleer kan word nic, maar die konscptuclc orde van betekenisse wat verantwoord moet word. Prakties betcken dit dat ek hicrdie byecnkoms nie as 'n blote inligtingsvergadering beskou waartydens ek $u$ van feitelike informasie omtrent dic Neomarxisme moet voorsien nie. Filosofies gesproke, is die Neomarxisme nie 'n empiriese verskynsel wat vanuit 'n soort toeskouershouding bestudcer kan word nic. Dit verteenwoordig eerder' $n$ uitdagende teoretiese perspektief op mens en samelewing wat op persoonlike instemming aanspraak maak. My verhaal van vanmiddag is gevolglik nie bereken op kennisname nie, maar op standpuniname: ek hoop om u te betrek by 'n denkprobleem wat u sal aktivcer om sáám te begin filosofeer.

Ten einde u stap vir stap in tc lei in die filosofiese probleemstelling van die Neomarxismc, wil ek as volg te werk gaan:

- eerstens wil ek dic begrip "Neomarxisme" analiseer met dic oog op 'n formele omskrywing van die betekenis van die woord. Ek sal aanvoer dat dit betrekking het op die filosofiese vernuwing en hersiening van dic Marxistiesc teoric in die Weste.

- tweedens wil ck die filosofies-historiese konteks van die Neomarxisme omlyn ten cinde die basiese clmente van hul Marx-hersicning in die visier te kry. Dit sal blyk dat hierdie konteks bepaal word deur die tweeledige ervaring van die mislukte revolusie in die Ooste en die versuimde revolusie in die Weste.

- derdens wil ek dic grondmotief van die kultuurkritiek van die Neomarxisme skets. Dit sal $m y$ in staat stel om die stelling te verdedig dat 'n grondige kritick op Marx tcgelykertyd 'n kritiek op die grondslae van ons Westerse samelewing impliseer.

\section{BEGRIPSBEPAI.ING: DIE FILOSOFIESE VERNUWING VAN DIE MARXISTIESE 'TEORIE IN DIE WESTE}

Eersicns dan - 'n formele beskrywing van die begrip "Neomarxisme". Neomarxisme, so sal ek betoog, is 'n sambreelwoord; dit word egter ook as 'n skelwoord gebruik.

\subsection{Neomarxisme as sambreelwoord}

Die woord "Neomarxisme" is in 'n sekerc opsig 'n sambreelwoord. Daarmee bedoel ek dat dit as ' $n$ algemene noemer optree waaronder verskillende betekenisse kan skuilgaan. Ek wil onderskei tussen 'n brcër en 'n enger 


\section{Kirsten}

betckenis van Neomarxismc.

Dit spreck vanself dat alles wat vir Neomarxisme wil deurgaan minstens verband moct hou met die tcoretiesc werk van Karl Marx (1818-1883). Hiervolgens sou Neomarxisme dan breedweg gesien kon word as die wêreldwye beweging van Marxnavolging, d.w.s. as die verdere uitwerking van die teorie van Marx onder die invlocd van historicse omstandighede wat ontwikkel het ná die grondlegging van die Marxistiese gedagtegoed in die ofuvre van Marx en, in 'n mindere mate, Engels. Hoe grondliggend Marx se oorspronklike geskrifte ook al mag wees vir die mondiale verskynsel van die Marxisme, 'n mens kan nie die oë sluit vir die pluriforme gestalte van hierdie verskynsel nie. Vir die Marxisme geld ook: elke ketter het sy letter. Naas die huidige Sowjet-Kommunisme, die sg. Marxisme-Leninisme, is daar 'n hele reeks -ismes wat konkrete bewys lewer van die uitcenlopende en dikwels onversoenbare Marx-interpretasies binne die tradisie van Marx-navolging. Ek verwys u na die Trotskyĩsme, Revisionisme, Titoīsme, Maoïsme en Castroĩsme om maar by die bekendste variante te bly. En dan is ons ook goed bekend met die pogings van 'n Alexander Dubrek en 'n Lech Walesa om in Oos-Europa 'n sosialisme met 'n menslike gelaat te vestig.

As ' $n$ werkdefinisie is ons eerste omskrywing van Neomarxisme klaarblyklik te wydlopend om bruikbaar te wees. In 'nenger sin van die woord kan ons dié begrip daarom goedskiks reserveer vir die filosofiese tradisie van Marxnavolging in die Weste. Alhoewel die kwalifikasie "filosofies" die verskillende kommunistiese partyc op die Europese Vasteland uitskakel, beteken dit nog nie dat ons met ons definisie, binne die geografiesc begrensing van die Westerse wêreld, 'n homogene beweging gelsoleer het nie. Die verskynsel van die sg. "Westcrse" of "filosofiese" Marxisme verteenwoordig op sý beurt 'n uiters komplekse tradisic wat onmoontlik in 'n afsluitende definisie vasgevang kan word. Daarvan getuig alreeds die bestaan van 'n aantal kompcterende "standpunte", waaronder dié van 'n "kritiese", "wetenskaplike", "eksistensialistiese" en "strukturalisticse" Marxisme as dic vernaamste tel.

Ondanks diepgaande verskille in hul Marx-interpretasie, het hierdie en ander denkrigtings egter twee formele kenmerke met mekaar in gemeen wat dit reguerdig om dic tradisie van die filosofiese Marxisme in dic. Weste onder die algemene noemer van "Neomarxisme" tuis te bring. 'n Eerste kenmerk is dat in die praklyk deurgaans 'n beleid van politieke onafhanklikheid ten aansien van sowel die gevestigde kommunistiese partye van dic "Old Left" as die links-sosialistiese organisasies van die "New Left" gevolg word. 
Daarom dat Neomarxiste hul meerendeel vereenselwig met dic benaming van "Vrye Marxiste". Die feit dat hulle nie onderhewig is aan die geïnstitusionalisecrde druk en kontrole van partydissipline nie, bevry Neomarxistiese denkers en denkrigtings ook van die dwang tot skoolvorming en dogmatiese sistecmdenke. Oor dic algemeen openbaar hulle dan ook 'n teoreticse openheid en ideologiese onbevangenheid wat voldoen aan die hoogste standaarde van wetenskaplike integriteit. 'n Twcede kenmerk is dat alle variante van Neomarxisme geïnspircer word deur een en dieselfde tenretiese opgawe, $\mathrm{nl}$. om die "oorspronklike", historicse Marx in die Marxisme te rehabiliteer. Dit kom daarop neer dat gepoog word om die filosofiese nalatenskap van Marx te red en om dit onder die veranderende sosio-politieke en ekonomiese omstandighede van die 20ste eeu vir die moderne maatskappy toepaslik te maak.

Hierdie filosoficse rehabilitasieprogram ontleen sy teoretiese stukrag o.a. aan die lewendige dialoog wat die Neomarxisme sowel met die geskiedenis van die filosofic as met kontemporêre strominge in die filosofie onderhou. Vertikaal tree dit in gesprek met die Duitse filosofiese tradisie en analiseer veral die historiese en saaklike betekenis van Hegel se dialektiese metode vir die Marxisticse tcorie. Die heraktivering van die Hegeliaanse filosofie met die ong op 'n vernuwing van die dialektiese en kritiese karakter van dic Marxisme, is een van die grondmotiewe in die gedifferensieerde tradisie van die Westerse Marxisme. Horisontaal voer die Neomarxisme 'n intensiewe gesprek met eietydse filosofiese bewegings, wo. veral die eksistensialisme, die strukturalisme en die hermeneutiek. Dit het op die Europese Vasteland aanlciding gegee tot 'n situasic van wedersydse beïnvloeding. Encrsyds oefen Neomarxistiese denkrigtings direk en indirek 'n bewese invloed uit op die tydgenootlike filosofie, asook op aanverwante vakgebiede soos dic sosiale wetenskappe, dic teologie en die kuns- en literatuurtcorie. Omgekeerd word belangrike motiewe van eietydse filosofież en van die empiriese vakwetenskappe in die Neomarxisme opgeneem. Hierdie wisselwerking bevestig sowel die intellektuele spierkrag as die teoretiese openheid van die Neomarxisme. Feit is dat die diskussie tussen Neomarxistiese en ander filosofiese denkrigtings tot die gangmakende debatte behoort wat tans die filosofiese toneel op die Vasteland, en in 'n toenemende mate ook in die Anglo-Amerikaanse wêreld, bepaal.

Samevattend: ek het die begrip "Neomarxisme" formeel omskrywe as dic tradisic van die filosofiese Marxisme in die Weste. $\Lambda$ s sodanig verwys dit na daardie tradisie van Marx-navolging wat teruggevoer kan word na dic publikasic in 1923 van Lukaćs se Geschichle und Klassenbeu'usstsein en Korsch 


\section{Kirsten}

sc Marxismus und Philosophie; wat sedertdien belangrike eksponente in Sartre en L.efèbre, Bloch en Kolakowski, Althusser en Colletti gehad het; en wat sy filosofies mees ambisicuse en invloedryke formulering ontvang het in die sg. kriticse teorie van dic Frankfurter Schule waartoe o.a. Horkheimer, Adorno, Marcuse en Habermas behoort. Dit is in hierdie eng sin van die woord as 'n Westerse filosofiese verskynsel wat ek die begrip "Neomarxisme" verderaan gebruik.

\subsection{Neomarxisme as skeluoord}

Dic woord "Neomarxisme" is nie net 'n sambreelwoord nie; dit is tweedens ook 'n skelwoord. Ek bedoel hiermce dat dit ook in 'n pejoraticwe sin gebruik word om andersdenkendes neer te haal of verdag te maak.

Op hierdie nie-verhelderende betekenis van die woord wil ek nie in besonderhede ingaan nie. Ek volstaan om daarop te wys dat hieruit blyk dat die Neomarxisme in sekere kringe nog steeds 'n philosophia non grala is. Veral in Suicl-Afrika het die woord, om redes wat vanweê sy Marxistiese konneksies seker verstaanbaar is, 'n emosionele geladenheid bekom wat 'n crnstige en onbevange akademiese diskussie oor die Neomarxisme tot nog toc ernstig geknichalter het. In dié diskussie moct twee uiterstes vermy word. Enersyds mag die teorie van Karl Marx nic geïdentifiseer word met die offisiële staatsideologie van die Sowjet-Kommunisme om so 'n direkte verbindingslyn tussen Neomarxisme en kommunisme te bewerkstellig nie. Die Marxisme-Leninisme is 'n karikatuur van die teorcticse standpunt wat Marx verdedig het. In die Sowjet-ideologie is gesigspunte wat by Marx slegs 'n marginale funksie beklee het, tot uitgangspunt verklaar, waardcur 'n fundamentele perspektiefwysiging plaasgevind het - aanvanklik uit teoretiese oorweginge by Engels, Kautsky en Plekhanov; later om praktiespoliticke en opportunisties-propagandistiese redes by Lenin en Stalin. Andersyds is dit ' $n$ ewe groot misgissing om Marx vry te pleit van enige aansprecklikheid vir dic repressiewe totalitêre regimes en terreurorganisasies wat in sy naam operecr. Hongarye, Praag, Afghanistan en Pole is nie toevallige ontsporinge in die wêreldwye opmars van die Marxisme nie. Soos wat ek hoop om aan te toon, loop daar' $n$ gouc (of is dit ' $n$ rooi?) draad vanaf Das Kapital na die Goelag Argipel.

Hieruit moet te duidelik wees dat die Ncomarxisme 'n ewewigtige oordecl verdien. Vir dicgene wat dit oorhaastig as skelwoord inspan, stel ck voor die houding van die fynproewer: wag eers, proc dic woord in u mond, voordat $u$ 


\section{Neomarxisme}

dit uitspocg en 'n oordeel vel. 'n Mens moct onthou: elke definisie, elke oordeel is voorlopig. Dit kan miskien wees dat woorde soos Neomarxisme wat ons tocgemaak het met vaste, ongunstige betekenisse, opgemaak moct word vir ander betekenisse, en moontlik betckenisse wat waardes insluit waarby ons direk gemoeid is.

\section{KONTEKSBEPALING: DIE TWEELEDIGE ERVARING VAN DIE MISL,UKTE EN DIE VERSUIMDE REVOLUSIE}

Ek het nogal uitvoerige aandag gegec aan 'n formele omskrywing van die begrip "Neomarxisme". Ek wou u daarvan oortuig dat die Neomarxisme'n suiwer, rasegte filosofiese beweging is en nie een of ander kruisgetcelde, ideologies- ontaarde en Moskou-geborgde onderneming nie. In dié verband het dit dan ook geblyk dat die "neo" in Neomarxisme staan vir die filosofiese hersiening en vernuwing van die Marxistiese teorie in die Weste. Dit is by hierdie laaste gedagte wat ek wil aansluit as ek vervolgens probeer om ons formele begrip van Neomarxisme inhoudelik in te klee. Ek wil my inhoudelike analise $\mathrm{nl}$. begin deur te verwys na die filosofies-historiese konteks van dic Neomarxistiese denke ten einde die basiselemente van hul Marx-hersiening in die visier te kry.

\section{I Marx in hersiening}

Vanuit 'n bepaalde perspektief kan die sentrale probleemstelling van die Neomarxisme as volg geformuleer word: hoe kan' $n$ mens nog Marxislies dink in 'n uêreldsituasie wat skynbaar nie langer revolusionèr is nie?? Die filosofies-historiese konteks van die Neomarxisticse denke word bepaal deur die tweeledige crvaring van die mislukking van die revolusie in die Ooste $\mathrm{en}$ die versuim van die revolusic in die Weste. Dit beteken dat Marx se optimistiese geloof in 'n proletariese revolusie wat menslike lyding en onderdrukking wêreldwyd sal afskaf, in meer as een opsig ont gogel is. Die heilshistoriese, Messiaanse rol wat Marx aan die arbeidersklas tocgeken het, kan nic langer gehandhaaf word nie. In dic Weste gaan dit met dic revolusie soos met die Messias in die Judaïsme: Sy koms is voorlopig en, tot nadere kennisgewing, blykbaar permanent uitgestel. In die Ooste, daarenteen, misluk die Oktoberrevolusie van 1917 in feite: in die Stalinisme openbaar die Messias hom as 'n valse profeet. Hicrby kom vir die Neomarxisme nog 'n derde en deurslaggewende ervaring: die Fascisme. Nie alleen het die Messias sy koms uitgestel cn staan daar 'n valse Messias op nie, maar in die nasionaal-sosialistiese moordbendes verskyn die anti-Messias in lewende lywe op die wêreldhistoriese toneel. Volgens hierdie interpretasic van die toestand van die rede 


\section{Kirsten}

en die vryheid in die wêreld, is die scenario van Marx reddeloos deur die geskiedenis gediskreditcer. Die dubbele crvaring van die verraaide en die verspeelde revolusie noop sy Neomarxistiese navolgers gevolglik om wesenlike leerstellinge van die Marxistiese tcorie drasties in hersiening te neem.

Wat het dan skeef geloop inet Marx se teorie? Waar het hy die bal misgeslaan? Daar is nouliks 'n lecrstelling van Marx te noem wat nog nie deur Neomarxistiese outeurs aan revisie onderwerp is nie. Terwyl almal dit met mekaar cens is dat die Marxist iese tcorie'n opknapping dringend nodig het, bestaan daar groot onduidelikheid oor dic aard en omvang van so 'n verjongingskuur. Wát presies hersien moet word en hoe radikaal hierdie hersiening deurgevoer moet word, vorm een van die deurlopende diskussietemas in Neomarxistiese geledere. Ek meen egter dat daar 'n redelike mate van eenstemmigheid bestaan oor die feit dat die basiese defek in die hart van die Marxisticse teorie gesock moet word, t.w. in die sg. historiese materialisme. Ek noem die historiese materialisme (Marx se materialistiese geskiedenisfilosofie) die hartaar van sy hele teorie, omdat dit die lewensbclangrike verbinding vorm tussen die kritick van die politicke ekonomie (Marx se kritiek van die kapitalistiese maatskappy) en die revolusietcorie (Marx se opvatting van dic proletariaat as die subjek van die revolusionêre praktyk). In sy beroemde 11 de tese oor Feuerbach, verklaar Marx dat die filosowe die wçreld alleen verskillend geïnterpreteer het; dit kom nou daarop aan om dit te verander. Sy geskicdenisbegrip het die funksie om die oorgang van die teorie (van die kapitalistiese maatskappy) na die praktyk (van die proletariese revolusie) te fundecr. Volgens sy Neomarxistiese kritici verloop hierdic oorgang - die sg. prakties-word van die teorie in die revolusie - nie so glad as wat Marx dit in sy historiese materialisme gekonsipieer het nie.

Veral twee punte van kritiek word geopper. Hierdie tweeledige kritiek is veral gemik op wat ek die reduktivistiese en deterministiese elemente van Marx se geskiedenisopvatting wil noem. Ek sal dit kortliks probeer verduidelik.

\subsection{Marx se ekonomiese reduktivirme}

Met Marx se redukfivisme (van reduksie-herleiding) bedoel ek die oortuiging dat die infrastruktuur of ekonomiese onderbou van 'n samelewingsorde eensydig die suprastruktuur of kulturele bobou bepaal. Marx word tereg die grootmeester van die infrastrukturele denke genoem. Dit is dic oorspronklike insig van sy historiese materialisme dat die geskiedenis vanuit die sentrale gesigspunt van dic mens se interaksie met die natuur in die arbcid gesien moet word. Die geskiedenis beweeg op verskillende fronte vooruit; die 


\section{Neomarxisme}

beslissende front is egter die materiële produksieproses, d.w.s. die proses waarin die mens sy fisiese bestaan en voortbestaan verseker deur die natuur aan sy wil te onderwerp en só vir hom 'n bruikbare wêreld te skep. Die wyse waarop die mens sy stollike bestaan voortbring deur die uitoefening van sy bcheersingsmag oor die natuur, bepaal alle vorme van sy maatskaplike lewe en vorm as sodanig die ware grondslag van die geskiedenis. Gevolglik meen Marx om al die sg. idcologiese vorme van die sosiale, politicke en geesteslewe van die mens in terme van hul ckonomicse basis tc kan verklaar deur dit tot blote funksies van die materiële arbeidsproses te herlei.

Volgens die Neomarxisme is een van die onhoudbare konsekwensies van só 'n reduktiewe gedagtegang dat Marx uiteindelik gedwing word om die veelkantige probleem van die emansipasie van die mens tot 'n bloot tegniesc probleem te verskraal. Deurdat hy die historiese ontwikkeling van dic mensheid uitsluitlik in materieel-ekonomiese terme interpreteer, dink liy die revolusionêre aktiwiteit van die menslike bevryding tcn slotte in een en dicselfde kontinuum as die tegniese proses van natuurbehecrsing. Die revolusionêre praktyk, d.w.s. die sosiaal-politieke aksie met die oog op die omverwerping van die kapitalistiese stelsel, word herlei tot die arbeiderspraktyk, tot tegniese handeling met die oog op dic ontwerp van 'n bruikbare wêreld. Die veronderstelde kwalitatiewe ommekeer wat die proletariese revolusic volgens Marx in die geskiedenis sou moes bewerkstellig, word daardeur gelykgeskakel. Ten slotte val kapitalisme en kommunisme saam in die cendimensionele beweging van die natuurbeheersende rede, van die bloot kwantitaticwe verhoging van die arbeidsproduktiwiteit.

Hierdic eensydigheid van Marx se geskiedenisbeskouing werp volgens Neomarxiste' $n$ verhelderende lig op die mislukking van die revolusie in die Ooste. Die outoritêr-burokratiese organisasie van die samelewing in die kommunisme hou verband met 'n latente grondtrek van Marx se historiese materialisme. Die teoretiese wortel van die degenerasic van die sosialisme tot ' $n$ totalitêre dwangsistecm moct gesoek word in Marx se hantering van dic arbeid as die paradigma vir menslike handeling as sodanig. Immers, indien die sosiale en politicke ordening van die samelewing gekonsipicer word volgens die voorbeeld van die produkticwe toe-eiening van die natuur in die arbeidsproses, dan word inderdaad die ganse werklikheid - mens en samelewing ingesluit - as roumateriaal beskikbaar gestel aan die willekcur van 'n totalc magsuitoefening.

Dic kommunistiese eksperiment het op ondubbelsinnige wyse aangetoon, so betoog die Neomarxiste, dat tegnies-wetenskaplike vooruitgang nie op 


\section{Kirsten}

sigself tot die sosiale en politieke emansipasie van die mens lei nie. Die bevryding van mens en samelewing van die mag van die natuur, is nie ook vanselfsprekend en onmiddellik 'n vermindering van sosiale nood en politieke onderdrukking nie. Dit is 'n illusie om te dink dat 'n vry en menswaardige samelewing outomaties volg op 'n herstrukturering van die ekonomiese infrastruktuur. Gevolglik konsentreer Neomarxiste hul aandag op die ont wikkeling van ' $n$ alternatiewe model van rasionaliteit wat elies en polities verruim is. Vanuit hierdie gesigspunt behels die filosofiese rehabilitasie van Marx die uitwerk van 'n redebegrip wat voorsiening maak vir beide "arbeid" en "interaksie", d.w.s. vir beide die dimensies van tegnieswetenskaplike (instrumentele) handeling én van sosiaal-politieke (kommunikatiewe) handeling.

\subsection{Marx se historiese determinisme}

Met Marx se determinisme bedoel ek sy ongeskokte vertroue in die rasioneelgewaarborgde goeic afloop van die geskiedenis. Dit is een van die belangrikste aansprake van Marx dat hy 'n element van noodsaak in die feitelike ontwikkeling van die geskiedenis ontdek het. Hierdic element, so het geblyk, is geleë in die wyse waarop dic materieel-ekonomiese basis van die samelewing, d.w.s. groei van die mens se arbeidskapasiteit, die totale lewe van die mens bepaal en as't ware as maatstaf dien vir die vooruitgang van die vryheid en die redelikheid in die geskiedenis. Dit is hierdie insig wat Marx in staat stel om met sy historiese materialisme die brug tussen teorie en praktyk te slaan. Hy verstaan sy teorie as 'n teorie van die revolusionêre praktyk. Die revolusionêre praktyk sien hy egter as die resultaat van die begrepe geskiedenis, d.w.s. van die teoretiese insig in sowel die praktiese noodsaak as die historiese onvermydelikheid van die revolusie. Die Marxistiese teorie staan of val by die tese dat die geskiedenis in die gestalte van die verarmde werkersklas, sélf en met 'n innerlike noodsaak die subjek produseer wat in staat én gewillig is om die kapitalist iese sisteem met geweld omver te werp.

Neomarxistiese kritici van Marx wys só 'n deterministiese gedagtegang om twee redes af. In die eerste plek is die teoretiese konsekwensies daarvan vir hulle onaanvaarbaar. Dit sou beteken dat die rol van die proletariaat in die revolusionêre proses verskraal word tot die funksie van willose eksekuteurs van die voorafbepaalde grondplan van die geskiedenis. In feite word Marx uiteindelik ook daartoe verlei om die revolusie af te lei uit die ekonomiese antagonismes van die kapitalistiese maatskappy i.p.v. om dit prakties in die sosiaal-politieke klassestryd van die proletariaat te fundeer. M.a.w. die 
revolusie blyk nie langer die uitdrukking te wees van die geskiedenismakende aktiwiteit van die arbeidersklas wat bewustelik vorm gee aan die sosialc en politieke lewensprosesse nic. Dit moet daarenteen verstaan word as die onvermydelike produk van die inherente logika van die materiële arbcidsproses wat, onafhanklik van en buite die wil van revolusionêres om, die sukses van die revolusie waarborg.

Marx se historiese determinisme is nie net teoreties onhoudbaar nie; dit is onk empiries deur die feitelike verloop van die geskiedenis gefalsifiecr. Die revolusie bly $\mathrm{nl}$. in die Weste agterweë. Volgens die Neomarxisme is die rede hiervoor die dokumenteerbare feit dat die tradisionele draer van die revolusie, die arbeidersklas, eftcktief in die moderne welvaartmaatskappy geintegreer is en sy belang só onlosmaaklik daaraan verbind het, dat hy sy revolusiontere potensiaal volledig ingeboet het. Deurdat die werker m.b.v. die manipulasiemeganisme van behoeftebevrediging in die bestaande sisteem ingelyf word, word die maatskaplike teenstellinge en konflikte wat tot bewuswording van sy onderdrukking en onvryheid kon lei, toegedek en die strewe na 'n kwalitatiewe verandering van sy sosiale lewensomstandighede cffcktief geblokkeer. D.w.s. die strewes en aspirasies van die werkersklas word by voorbaat só kunsmatig deur die manipulasietegnicke van die welvaartmaatskappy gevorm en gerig dat dit steeds in beginsel binne die bestaande bestel geakkommodeer en bevredig kan word. In dié opsig verskil die arbeidersklas nie langer kwalitatief van ander sosiale klasse nie - soos ons almal, is die moderne arbeider in die Westerse wêreld 'n matericel bevredigde, maar tegnologies gemanipulecrde verbruiker.

Die versuimde revolusie in die Weste, so argumentecr die Neomarxisme, weerle Marx se aanspraak dat daar 'n objektiewe logika in die geskiedenis werksaam is, die logika van tegniese rasionalitcit wat met ' $n$ innerlike noodsaak die bevryding van die mens uit sy verslawende omstandighede sal bewerkstellig. Dit beteken dat die geskiedenis sélf dic hoop op 'n ekonomiesgefundeerde revolusie die nekslag toegedien het. Die konsckwensic van hierdie diskreditering van die materic̈le basis van die geskiedenis, is dat die krit ick en verandering van die kulturele bobou by Neomarxistiese outeurs 'n nuwe en deurslaggewende gewig verkry. Die bevryding van die mens - vir sover so iets hocgenaamd nog moontlik is - berus nie op die eiewetlike gang van die geskiedenis nie. Dit hang af van die daadwerklike insette van cmansipasicbewuste mense wat met wil en bewussyn hul eie geskiedenis maak. Voorlopig kom alles daarop aan om d.m.v. ideologickritick valse bewussynsvorme te besweer. Die klemverskuiwing binne die Maixistiese tcorie waarvolgens die bobou algaande aan belangrikheid wen ten kostc van 


\section{Kirsten}

die onderbou, kom daarin tot uitdrukking dat die kritiek van die politieke ekonomie vervang word deur 'n kritiek van die instrumentele rede. In hierdic opsig bestaan die filosofiese rehabilitasie van Marx in die oorgang van die Marxisticse kritiek op die kapitalistiese ekonomie in 'n kritiek op die tegniese beskawing.

Samevattend: ek het probeer aantoon hoe die Neomarxistiese hersiening van Marx deur die dubbele ervaring van die mislukte en die versuimde revolusie be paal is. Die mislukking van die Bolsjewistiese revolusie vestig die aandag op die reduktivistiese element in Marx se historiese materialisme. Dít probcer die Neomarxisme eliminecr deur die invocring van 'n verruimde begrip van die rede, d.i. 'n redeopvatting wat ruimte maak vir sowel die tegniese as die eties-politiese aspekte of dimensies van menslike rasionalitcit. Die versuimde revolusie in die Weste vestig op sý beurt die aandag op die valse determinisme van Marx sc geskiedenisvisie. Dít probeer die Neomarxisme ontkom deur die belang van die kulturele bobou in ere te herstel, d.w.s. deur die wetenskaplike bestudering van die ekonomiese bewegingswette van die kapitalisme te vervang met die ideologieskritiese ont maskering van die eensydige, tegnies-verskraalde redeopvatting waarop die moderne Westerse beskawing gebou is.

Hierdie twee samehangende, kultuurkritiese denkmotiewe van die Neomarxisme wil ek nou ietwat duideliker omskryf deur dit te verbind met 'n derde motief, $\mathrm{nl}$. hul fundamentele bevraagtekening van die tradisionele Westerse vooruitgangsgeloof. Auschwitz en die Fascisme is volgens Neomarxiste nie ' $n$ tydelike en toevallige onderbreking in die opmars van die vooruitgangsreus nie. Inteendeel, die wesensaard van die Westerse beskawing word daarin onthul.

\section{STANDPUNTBEPALING: KULTUURKRITIEK AS 'N TWEESNYDENDE SWAARD}

Ek wil nou 'n kort, samevattende skets gee van die grondmotief van die Neomarxist iese kultuurkritiek. Dit sal my in staat stel om die tese te verdedig dat 'n grondige kritick op Marx tegelykcrtyd 'n kritick op die grondslae van ons Westerse samelewing impliseer.

\section{I Die tegnokratiese vooruitgangsideaal}

In 1920 skryf John Bury in sy standaardwerk, The Idea of Progress, dat die vooruitgangsidce die "animating and controlling idea of Westcrn civili- 
sation" is. "For the earthly progress of humanity", so verklaar hy, "is the general test to which social aims and theories are submitted as a matter of course. The phrase civilisation and progress... illustrates how we have come to judge a civilisation good or bad according as it is, or is not, progressive". Wat Bury hier vertolk, is die neerslag van bykans 200 jaar van Westerse beskawingsoptimisme - 'n optimisme wat georiënteer is aan wat ek die tegnokratiese vooruilgangsideaal wil noem. Met "tegnokrasie" bedoel ek in dié verband 'n beskawing waarin die kratos, die mag van wetenskap en tegniek dominant geword het. As sodanig is die Westerse vooruitgangsideaal o. a. dic historiese erfenis van die ontmocting van wetenskap en tegniek aan dic begin van die sewentiende eeu. Dit is 'n produk van Bacon se uitspraak dat kennis ván, ook mag óór die natuur beteken. Met die uitspraak "Knowledge is power" voorsien hy die ont wakende homo faher, die makende mens, van die stelrcël waarvolgens hy sedert dien sy verhouding tot die wêreld gekonsipieer het as cen van die produktiewe onderwerping en toe-eiening van die natıur. Die Westerse idee van vooruitgang gaan m.a.w. oorspronklik uit van die tegnokratiese identifikasie van die vryheidsbegrip met die akkumulatiewe ontplooiing van die mens se beskikkingsmag oor sy wêreld. Gevolglik is die natuurbeheersende rede in 'n toenemende mate as die draer én die maatstaf van die vooruit gang van die mens erken en vereer - totdat die vooruitgangsideaal in die loop van dic 19 de eeu eksklusief aan die voortskryding van wetenskaplike kundigheid en tegniese vernuf verbind is en tegnies-wetenskaplike vooruitgang ten slotte tot die paradigma van menslike vooruitgang verhef is.

Dit is een van die traumatiese ervaringe van die 2 de helfte van die 20ste eeu dat die eens magiese towerwoord van die vooruitgang, waaroor Bury in 1920 nog so liries kon raak, op baie fronte van dic Westerse kultuur sy gcloofwaardigheid begin verloor het. Daar bestaan vandag, minstens in intellektucle kringe, 'n wydverspreide kritiese onbehae in die Westerse kultuur. Elke tydvak in die Westerse kultuurgeskiedenis het weliswaar sy kritici gehad. Kenmerkend van die huidige kritiese onbehae is egter die strukturele en die radikale aard daarvan. Dit is struktureel, omdat dit geen konjunkturele verskynsel is wat aan 'n toevallige samcloop van omstandighede gewyt is en daardeur as ' $n$ verbygaande modegier algemaak kan word nie. Dit het te make met iets wat inherent is aan dic moderne Westerse wêreld, met sy wcsensaard. Hedendaagse kultuurkritiek sinjalcer nie 'n krisis in die Westerse kultuur nie, maar die krisis ván die Westerse kultuur. Daarom is hicrdie kritick ook radikaal. Dit is nie bloot teen bepaalde fasette of geisolecrde instellinge van die samelewing gerig nie. Dit bevraagteken daarenteen die radix, die wortels of grondslae en daardeur die totale 


\section{Kirsten \\ waardesistcem waarop ons beskawing berus.}

Dit is tcen hierdie agtergrond dat die basiese denkmotiewe van die Neomarxistiese kultuurkritick bcoordeel moet word. Die strukturcle en radikale aard van hierdie kritiek blyk daaruit dat dit nou juis die tegnokratiese vooruitgangsideaal is wat onder die loep geneem word. Die sentrale insig wat Neomarxistiesc kultuurkritici verkondig, is dat die mens deur sy georganiseerde tegniese onderwerping en eksploitering van die natuur nie sy beloofde vryheid verwerf het nie. Die blinde geloof in die emansipatoriese, bevrydende werking van wetenskap en tegnick het cerder 'n waarde-oriëntasie in die lewe gerocp wat goedskiks met die begrip utililarisme of operasionalisme getipeer kan word. Daarmee word 'n waarderingskema bedoel wat die waarde van 'n saak van die funksioncle nut daarvan laat afhang. Die strategiese doel van 'n operasionalistiese kultuurbeleid is die bewoonbaar makk van dic wêreld deur die tegnies-wetenskaplike beheersing en manipulasie van alle moontlikhede.

Die enigste norm wat hierby in die geding is, is nie die normatief-ctiese vraag of iets gedoen behoort te word nie, maar die funksionele vraag of dit tegnies moontlik is al dan nie. Hieruit volg ten slot te dat nic net die natuur nie, maar ook die mens sélf van sy intrinsicke eie-waarde ontneem word. Gecn wonder dan ook, aldus die Neomarxisme, dat die Westerse beskawingsgeskicdenis in feite 'n blocdige slagbank is waarop die lewens van miljoene onskuldige mense aan die ydele ideale van "beskawing", "vooruitgang" en "vryheid" geoffer is nie. Die veronderstelde parallelle ontwikkeling van natuurbehecrsing en vooruitgang, van arbeid en vryheid, tegniek en humaniteit, wetenskap en geluk, welvaart en welsyn word nie deur die huidige toestand in die wereldl bevestig nie. Auschwitz, Hiroshima, die Goclag Argipel, en noem maar op, kon alleen plaasvind in 'n beskawing waarvan die waardesistecm alles en almal tot tegnies beheer-en manipuleerbare funksies en operasies herlei.

\subsection{Die dialektiek van die vooruilgang}

Die Neomarxistiese diagnose van die huidige stand van die rede, die vryheid en die menslikheid in die Westerse wêreld, lei tot die tese i.s. die sg. dialektiek van die vooruitgang. Daarmee word bedoel dat die beskawingsproses van tegniese natuurbeheersing sy negaticwe teendcel produseer, en dit ten koste van die menslike subjek sélf. Die blyk nl. dat met die voortgaande ontplooiing van dic (tegnokratiesc) mag van die mens oor sy wêreld, ook die (burokratiese) mag van die mens oor die mens toeneem. D.w.s. in dieselfde 
mate as wat die ontokrasie van die natuur opgehef word, verstrik die mens hom in die cwe anonieme magsistecm van die hedendaagse tegno- en burokrasic. In sy poging om hom uit die ondeursigtige magte van die natuur te bevry, word die mens dus deur' $n$ nuwe alhanklikheid oorval - in die vorm van sy eic arbeid en organisasie. Die tegniese bevrydingsproses slaan gevolglik in sy teendeel om: die mens wat hom met sy tegnics-wetenskaplike magsapparaat uit die natuur wou bevry, word nou die slagoffer van sy cie, ongebreidclde wil tot mag.

Die tese i.s. die dialektiek van die vooruitgang, hierdie ommekcer van subjek cn objek in die beskawingsproses, vorm dic spil waaromheen dic Neomarxistiese kultuurkritiek wentel. Dit gee ook 'n aanduiding van die groot afstand wat Neomarxiste van hul leermeester skei. Soos aangedui, radikaliseer hulle Marx se kritiek van die politieke ekonomie, d.w.s. sy ka pitalismekritiek, tot 'n kritick van die instrumentele rede, d.w.s. 'n kritiek van die tegniese beskawing. Die rede hicrvoor is dat dit in die Westerse samelewing nie langer een, bepaalde klas - die werkers - is wat deur ' $n$ ander klas - die kapitaliste - uitgebuit en onderdruk word nie. Die teenstelling tussen arbeid en kapitaal verval ten oorstaan van die onderdrukking wat die moderne tegnokratiese bestel sonder aansiens des persoon uitoefen. Met die konsep van die dialektiek van die vooruitgang wil die Neomarxisme juis sê dat homo sapiens as sodanig ' $n$ vervrcemde, onderdrukte en verslaafde spesie geword het - en dit deur sy eic tocdoen. Die homo faber, die (legnokraties) makende mens, maak homself tot 'n homo fabricalus, 'n (burokraties) vervaardigde mens. Volgens Neomarxiste is die lyding en ellende in die wêreld clus nie die dirckte gevolg van die vervreemdende werking van die kapitalistiese ekonomiese stelsel, soos Marx dit wou hê nic. Die bron van die kwaad moet veel dieper as in 'n histories-bepaalde produksiesisteem gesoek word. Die kapitalisme en sy mensonterende neweprodukte is alleen 'n simptoom van die magstrewe van die mens wat in die Weste gelei het tot dic vesting van 'n tegnokratiese bestel. Dit is die magsbeginsel inherent aan die moderne Westerse opvatting van die rede as 'n instrument van natuurbeheersing, wat ten grondslag lê aan alle vorms van onderdrukking en onmenslikhcid in die wêreld. Hierdie prinsipe van die mag is ook die blindevlek van die teorie van Marx. Soos aangetoon, word Marx se kritiek van die polit iekc ekonomie séll nog bepaal deur die optimistiese geloof in die bevrydende werking van die natuurbeheersende rede. Dic ontwikkeling van die produksiekragte en die groci van die arbeidskapasiteit gee nl. die voorwaardes aan vir ' $n$ rcvolusionêre herstrukturering van die kapitalistiese produksicorde. In dié opsig was Marx niks minder tcgnokraties as 'n Milıon Friedman nic! Meer nog: alle ideologiese verskille ten spyt, vertoon 


\begin{abstract}
Kirsten
sosialistiese en kapitalisticse samelewings volgens Neomarxiste een en dieselfde repressicwe kenmerke, omdat hulle op cen en dicselfde tegnokratiese grondslag berus. Of die samelewing nou ckonomies georden word volgens die vrye mark-beginsel of die beginsel van sentrale beplanning, in beide gevalle is die wagwoorde: kwant itaticwe groci, tegnies-wetenskaplike vooruitgang, industriële ontwikkeling; kortom, die intensicwe en ekstensticwe uitbreiding van die mens se mag oor sy wêreld. Die rooi draad wat Das Kapilal en die Goclag Argipel verbind, die wil tot mag, vorm dus ook 'n deurlopende motief in die ontstaan en ontwikkeling van die kapitalist icse maatskappy. Wanncer ons dus die Marxistiese tcorie grondig ondersoek, ontdek ons ook krake in die grondslac waarop ons eic samclewingsorde berus. Dit is daarom nie wetenskaplik ecrlik om Marx en die kommunisme a an kritick te onderwerp sonder om tegelykertyd selfkritiek uit te ocfen nic: ons verkeer almal onder dieselfde ideologiese ban - die tegnokraticse verheerliking van die natuurbeheersende, wêreldverowerende rede. Ten slotte enkele opmerkinge hicroor.
\end{abstract}

\title{
3.3 Die bemeestering van ons meesterskap
}

Soos wat uit hul Marx-kritiek afgelei kan word, skryl Neomarxistiese clenkers die dialektick van die vooruitgang toe aan die verskraalde kultuurbegrip wat sedert die 16de ceu in die Weste posgevat het; 'n kultuurbegrip waarin arbeid en materiële produksie ten koste van kommunikasie en sosiaal-politieke interaksie die klem ontvang het. Hierdie verskraalde kultuurbegrip wat deur die huidige ideologiese karakter van wetenskap en tegniek en die blinde geloof in tegnies-wetenskaplike vooruitgang versinnebceld word, word op sý beurt gewyt aan 'n eensydige redeopiatting; 'n opvatting van die rede waarin die teoreties-berekenende aspek ten koste van die prakties-etiese aspek die oorwig verkry het. Die gevolg hiervan was dat die Westerse idee van rasionaliteit allengs uitsluitlik in die teken van natuurbeheersing, van tegnologiese magsontplooiing en "social engineering" te staan gekom het, met uitsluiting van die elemente van versoening, van magsvrye dialoog en politieke konsensus.

Fk wil my in die brë vereenselwig met dic Neomarxistiese diagnose van die Westerse kultuurkrisis. Die sosiale evolusie van die mensheid is 'n bidimensionele proses wat as't ware op twce bene staan. Hierdic benc kan, in navolging van Habermas, goedskiks aangedui word met dic tcrme "arbeid" en "interaksie". Met arbeid bedocl ek in hierdic verband die materiële produksie en reproduksie van die lewe in wissclwerking met die natuur. Hierdie proses word bepaal deur dic legniese interesse in natuurbeheersing 


\section{Neomarxisme}

met dic oog op die emansipasie van die mens uit sy natuurlike nooddruf $\mathrm{cn}$ dic fisicse sekerstclling van sy bestaan en voortbestaan. Interaksie, daarenteen, dui op die sosiale produksie en reproduksie van die lewe in kommunikasie met die ander d.m.v. die taal. Hicrdic been van die evolusicproses word gelei deur dic etiese interesse in die wedersydse verstaan van mekaar met dic oog op die bereiking van ' $n$ politicke konsensus oor die sosiale en ckonomiese ordening van die maatskappy. Arbeid en interaksic vorm, sowel in 'n histories-genetiese as in 'n prinsipicel-strukturele opsig, dic twee noodsaaklike voorwaardes waaronder die mens hom in die wêrcld oriëntecr en kultuur skep. In sy bewoonlbaar maak van die wêreld is dic kultuurskeppende mens net soseer aangewys op die tcgniese behecrsing van die natuur deur instrumentele, strategiese handeling as opdic normatiewc strukturering van dic sosiaal-politicke orde deur kommunikatiewe, morele handeling. Die emansipatoriesc funksic wat tegries-wetenskaplike magsont plooiing in dickultuurproses vervul het en nog steeds vervul, kan nie ontken word nie. Ek meen egter Neomarxiste slaan die spyker op die kop wanneer hulle die dilemma van die Westersc kultuur verbind met die oorwockering van interaksie, van sosiaal-politicke kommunikasic cn dialoog, deur arbeid, deur die aktiwiteite van produksic en beplanning. I mmers, dic materiële voorsicning in die mens se lewensonderhoud is ' $n$ voorwaarde vir die mens se bestaan. Dit is cgter nie dic finale waarde van sy bestaan, soos wat dcur die utilitaristiese ctos van die hedendaagse tegno- en ekspertokrasie gesuggereer word nie. Dit belıels dat die redebegrip summier met tegnies-wetenskaplike rasionaliteit geident ifisecr word. Die gevolg hiervan is dat alle lewensterreine aan die magshecrskappy van wetenskap en tegniek uitgelewer word - ook dić terreine, soos bv. dic samelewing, die politick en die moraal, waarin alleen die versoenende handeling van konsensussockende dialoog bevrydend kan werk. Dit is hierdie oorwockering van interaksie deur arbeid wat ten grondslag lêt aan dic dialcktick van die vooruitgang, aan dic ommekcer van subjek en oljjek in die beskawingsproses.

Is die Westerse mens in staat om hom aan hierdic dialektick te ontworstel en om die noodlottige konsekwensies van dic objek-word van dic menslike subjek af te wecr? Van die beantwoording van hicrdie vraag, so meen Neomarxiste m.i. tercg, hang nie net af watter soort toekoms ons in die Weste gaan hê nie, maar of ons hoegenaamd 'n tockoms gaan hê. Immers, dic kollektiewe selfmoord van dic menslike spesie is vandag net so 'n grillerige gedagte as wat dit 'n tegnies-uitvoerbare saak is. Ons is die ecrste geslag wat as't ware dic $\Lambda$ pokalipse behecr. As die Neomarxisme cén verdienste het, dan is dit dat dit die grondaannames van ons Westerse kultuur radikaal problematies gemaak het. Neomarxisle konfronter ons met die 


\begin{abstract}
Kirsten
waarheid dat die moderne Westerse mens hom danksy wetenskap en legniek meester gemaak hel van sy wêreld, maar dat hy hom nog nie kon meester maak van sy meesterskap nie. Ons het geleer om die natuur aan ons doeleindes te onderwerp; ons het egter nog nie gelcer om met onsself, met ons eie soort genote klaar te kom nie. Daar bestaan blykbaar geen konsensus oor die morele waardes, sosiale strukture en politieke institute; kortom, oor die kultuurbeleid wat die uitbreiding van ons wetenskaplike kundigheid en die ontwikkeling van ons tegniese vernuf moet begelei en rigting gee nie. Geen wonder dan ook dat die mens sy tegnies-wetenskaplike vermoëns destruktief teen homself aanwend nie - so veel so dat ons kultuur nie alleen deur ondergang bedreig word nie, maar sćlf diegene wat deel daarvan uitmaak met uitwissing bedreig.
\end{abstract}

Op die vraag hoe presies die mens hom meester van sy eie meesterskap moet maak, loop die menings uiteen. Eén ding staan egter vas: die mens se bemeestering van sy mecsterskap is self nie 'n tegnies-wetenskaplike aangeleentheid nie. Vir sover dit in die grond van die saak 'n kulturele heroriëntasie en daarmee ' $n$ hersiene self- en wêrelddefinisie vereis, is dit 'n filosofiese aangeleentheid. Dit wil my dus ten slotte lyk asof die Neomarxisme u daarvan wil oortuig dat die filosofie voorlopig nie verdien om afgeskaf te word nie! 